\title{
7. Mainstreaming climate change issues Challenges for journalism education in Indonesia
}

\begin{abstract}
This article aims to explain the challenges of journalism education in Indonesia on the issue of mainstreaming climate change. As the world's largest archipelago, Indonesia has to deal with some climate change impacts such as rising sea levels, extreme weather, floods, drought, and forest fires. Climate change is a real serious threat, but public awareness of this issue is low in Indonesia. Mass media have a capacity to mainstream climate change and increase public awareness. The data for this article has been collected through qualitative content analysis of newspaper articles, interviews with communication lecturers and scholars, and document reviews. Some of the important findings are: 1) The climate change issue in the Indonesian mass media is less popular than other issues such as corruption, elections, terrorism and refugees; 2) Journalism education in Indonesia does not contribute enough to mainstreaming climate change on mass media; 3) There are three levels of problem in macro, messo, and micro level of journalism education in Indonesia to mainstreaming climate change issue. At a micro level, the problem is related to the lack of lecturers with competence in climate change. On a messo level, journalism education has failed to connect with the problem of climate change through curricula. At a macro level, the problem is related to the popularity of journalism. Systemic theory by Niklas Luhmann was used as tool to analyse these problems. From this perspective, Indonesian journalism education as a system faces plenty of challenges to reduce the complexity of problems to optimise its role in mainstreaming climate change.
\end{abstract}

Keywords: climate change, Indonesia, journalism education, mainstreaming, mass media, systemic theory

\section{HERMIN INDAH WAHYUNI \\ Center for Southeast Asian Social Studies (CESASS), Universitas Gadjah Mada (Gadjah Mada University), Yogyakarta, Indonesia}

NDONESIA is the world's largest archipelago, conprising 17,000 islands including five main islands: Sumatra, Java, Borneo, Sulawesi and Papua. With a total population around 255 million, Indonesia is the fourth most populated country 
in the world. Nowadays, Indonesia is facing serious climate change problems. Indonesia shares vulnerability to climate change with many other countries (Garnaut, 2009). Sea level rise, increasing surface air temperature, extreme weather, drought, and forest fires are some of these problems (Bappenas, 2009). According to an Indonesia Environmental and Climate Change Policy Brief 2008 issued by the Swedish International Development Agency (SIDA), the impacts of climate change will be felt across many different sectors. Climate change affects the social economy dimension, including transportation, agriculture, health and industry. Many stakeholders are involved to solve these problems, ranging from government, private sector, NGO, and education institutions to journalists. However, inadequate sectoral policy coordination across government agencies and jurisdictions in Indonesia, as well as inadequate local capacity building become the obstacles that need to be overcome (Paulus \& Hindmarsh, 2016). Another serious challenge is how to increase climate change awareness, public engagement and action. Climate change awareness is greater in countries that are wealthier and more highly educated (Knight, 2016) such as some European countries, North America, and Japan (Arlt, Hope, \& Wolling, 2011; Leiserowitz \& Howe, 2015). In developing countries in Asia, Pacific, Africa or South America, to increase public awareness of climate change is a tough challenge (Ayers et al, 2014; Sina et al, 2016; Garnaut, 2009; Leiserowitz \& Howe, 2015).

Some researchers argue that mass media is an important actor to increase climate change awareness (Nisbet, 2009; Boykoff \& Boykoff, 2007; O’Neill \& Cole, 2009; Schmidt, Ivanova \& Schafer, 2013). From his research on seven cities in Indonesia, Putrawidjaya (2008) found that most students and teachers know about climate change from mass media. Dotson et al (2012) showed that climate change coverage in the Chilean national newspaper, La Nación, could lead its readers to believe that climate change is an important issue to address. Meanwhile, Sampei and Usui (2009) have shown that the increase of global warming media coverage in Japan has had an immediate influence on public awareness of global warming issues. Luhmann (2000) argued that knowledge about society, history, and nature, including the climate change issue, actually comes from mass media. Mass media is a system of information and knowledge. In society, mass media has some basic functions such as information, correlation, continuity, entertainment and mobilisation (McQuail, 2010). Mass media have the capacity to reach and affect large numbers of audiences. Television stations, books, newspapers and online media disseminate information and create culture (McQuail, 2010). Media is a system of framing and agenda-setting (McQuail, 2010). Media influences public awareness through agenda-setting and framing of news by selecting what is published, how frequently, and through what frames (Dotson et al, 2012). Print, electronic, and online media construct reality (Luhmann, 2000), shape public opinion (McQuail, 2010, p.515), create culture 
(Baran, 2006), and even mobilise social movement (Castells, 2009). Regarding this, journalists play an important role when they write articles or reports about climate change and other issues in newspaper columns or television programmes. Journalists are backstage actors that determine how media covers climate change. Castells (2009) emphasises that media are essential to increase awareness and many journalists are involved in these efforts.

While some research has focused on mass media coverage and climate change awareness, this study has tried to look further with journalism education as the focal point. This article has aimed to explain the challenges of journalism education in Indonesia to mainstream climate change issue. After 1998, the landscape of the mass media industry in Indonesia changed dramatically when the number of print and electronic media increased sharply. Consequently, the need by media companies for professional journalists increased rapidly. Along with this, communication and journalism departments have become among the most popular departments at universities in Indonesia. Communication departments or journalism programmes ideally create journalists with good ability and understanding on various issues, including climate change. However, in reality journalism education in Indonesia as a system faces some fundamental problems to be able to fulfil this expectation.

\section{Theoretical framework}

\section{System Theory}

System Theory is one of the strong tools of analysis available to understand the dynamics of the journalism education system in mainstreaming climate change as an issue. Journalism education from this theoretical perspective is a complex system which contains some sub-systems and many elements. Niklas Luhmann introduced his system theory called Autopoietic System Theory. Ritzer (2011) explained the characteristics of Luhmann's autopoietic system theory in simple terms: it produces basic elements that build the system itself; the system organises itself in two ways, arranging boundaries and internal structure; the system arranges its boundaries by determining parts of the system and parts of the environment using binary code; there is no direct link between system and its environment; however, system relates to representation of the environment.

Analysis of system theory focuses on connection between the system and its environment. Environment is everything else, or everything outside the system. Analysis of the difference between system and its environment starts with an assumption that system can never be more complex than environment (Luhmann, 2000). The relationship between the system and its environment is always asymmetric (Luhmann, 2000). To survive, a system has to reduce its complexity by differentiation process. 
How adaptive does the system give feedback to the environment? To measure it there are several concepts that should be considered: selection of problem complexities, autopoietic-self-referential, structural-coupling adaptation and differentiation. The basic definition of adaptive communication is a form of communication to adjust with certain change in the environment. In the case of journalism education of climate change, adaptive communication is defined as the capacity of the journalism education system to adapt with change and process information in order to cope with challenges.

\section{Media and climate change}

Mass media is an important and influential part of the information society. Main activities of media are to create and diseminate information, culture, and knowledge (McQuail, 2010; Luhmann, 2000; Baran, 2006). Information is a basic element that enables social systems to work. What people know about themselves, family, friends and their environment come from mass media (e.g. television, book, newspaper, magazine, radio, film or internet). McQuail (2010) explained that the power of mass media could attract and direct public attention, influence behaviour, and provide definitions of reality to audiences. Mass media is a system to construct reality (Luhmann, 2000). Media also has the ability and power to frame an issue. Media framing theory explains that media will organise principles that are socially shared and persistent over time, that work symbolically to structure the social world meaningfully (Reese, 2001).

Related to the climate change and environmental issue, mass media is a key actor to identify and interpret it (Boykoff \& Boykoff, 2007). Mass media also acts as an observer of society (Luhmann, 2000). Scholars from various disciplines identify climate change as one of our environmentally serious problems. Some scholars have tried to find out and explain about media, climate change and other relevant elements such as policy or journalism field (e.g. Gess, 2012; Smith, 2005; Shehata \& Hopmann, 2012; Takahashi \& Meisner, 2012). Kenix (2008) noted that the public learns about climate change not only through mainstream, but also alternative media. Schmidt, et al. (2013) explained that "media coverage may increase societal awareness and knowledge of the issue, ideally fostering informed individual and collective actions'.

Many media in many countries have put the climate change issue as an important topic. But, even though media coverage about climate change increased in many countries (Schmidt, et al., 2013), Boykoff and Boykoff (2007) have shown a problem when the characteristic of the media coverage of climate change often uses unfamiliar terms. Mass media, especially the journalists, sometimes use terms that are hard to understand by their audiences. The professional language has difficulty in being translated smoothly into the crisp, unequivocal commentary that is valued in the press. There are some notes from media people about 
problems in decision making regarding climate change issues.

Besides the internal issues within media and journalism, there are some external factors related to how the media influences the public sphere, namely quality of mediated politics. Some commentators in this domain discuss some factors that influence the optimism and the pessimism valued in climate change issues, i.e., 'media influence', 'journalistic practice' and 'the adequacy of coverage' (Gavin, 2009). Also, Gavin (2009) concludes that the coverage of climate change issues was very much influenced by politics of climate change policy in a country. Therefore, he suggests that the climate change policy must take this international public sphere into account to understand how the mitigation of global warming should be approached and encouraged with all its limitations.

\section{Media and journalism education}

Journalism school prepares students to be a 'real' journalist and work in media institutions. But from an ideal perspective, journalism education does not only prepare students to contribute in media industry, but also prepares them to understand about media and society then they can contribute positively. Ideally, journalists come from a journalism school in a university or academy. However, many journalists also come from other disciplines or schools such as law, economy, philosophy, even biology. The main debate in journalism education is whether journalists need to be college (university)-educated, whether they need a liberal arts degree, or whether they need professional education that combines liberal arts and practical training (Folkerts, 2014).

Trying to relate those environmental issues with the role of journalism education, the discipline plays an important role as the bridge to prepare students to enter journalism practice. Some educational goals have mentioned in a main research about communication education in Southeast Asian countries. There are three perspectives: ideal, media industry, and career in non-media industries (Hwa \& Ramanathan, 2000). Research in Indonesia has shown that the first aim of communication education in Indonesia is to help students prepare for their long term career in the media industry (Nasution, 2000, p. 59). From that research it is interesting to note that the main aim stated by the educators in Indonesia is not the aim of the ideal perspective, but that they highlight more the practice perspectives to prepare jobs in the media industry. This result is actually contrary to the role of the education that should highlight more critical and ideal aspects of journalism and not only the practical side. Thomas Hanitzsch (2001) conducted research about journalism education in Indonesia and showed some 'flaws' that constrain the journalism education curriculum, ranging from lacking synergy between education and industry, inadequate technology, to the issue of teaching staff with minimal qualifications. Some of it seems to have become the problems faced by journalism education in Indonesia until today. 
Wendy Bacon, a senior journalist from the Australian Centre for Independent Journalism (ACIJ) ${ }^{1}$ presented facts about 'media wars' in journalism education, in the case of Australia and to a more limited exent in New Zealand (Bacon, 2012). Media wars related to an issue about the relationship of cultural and media studies to the education of journalists. She highlighted that journalism education should focus on linking robust and informed journalism with the media research that contributes to social development both in the broader community, the media industries and inside the academy (Bacon, 2012). In climate change issues, this debate has relevance in which idealism and practical issues influence the decision making process.

\section{Methodology}

This study was conducted using a qualitative approach. The data was collected through some procedures, specifically observation, online content analysis and interview. Content analysis was the research method used to explore the content of media. Holsti (1969) defined content analysis as any technique for making inferences by objectively and systematically identifying specified characteristics of messages. Krippendorf (2004) described that content analysis examines directly communication via texts or transcripts, and is aimed at the central aspect of social interaction. This analysis was applicable for both quantitative and qualitative operations. It could also provide valuable historical/cultural insights over time through analysis of texts (Krippendorf, 2004). For this study, simple content analysis was applied with qualitative style. This method of application aimed to describe the tendency and comparison of the numbers of articles with specific keywords.

The object of content analysis in this study is climate change issues coverage of Kompas, a mainstream as well as the largest newspaper in Indonesia. The research procedures implemented were: first, collecting some relevant articles which were selected with certain keywords on the online version of Kompas. In this study, articles from Kompas were obtained through e-paper access (epaper. kompas.com) and Kompas Information Center (pik.kompas.co.id). Secondly, the articles were analysed using determined unit of analysis. Main unit of analysis in this article was keyword 'environmental issue'. This keyword was used in two aspects. Firstly, environmental issue coverages were compared with other public issues, and secondly, varieties of environmental issues that had been covered by newspaper were mapped.

Observation was chosen as a collecting data method to catch information related to the landscape of mass media or communication education in Indonesia, as well as the social context of climate change issue. The portrait of communication science and journalism education development in Indonesia was obtained from some websites, such as the website of the Ministry of Research and Higher 
Education as well as the official database of the Accreditation Board of Higher Education (http://ban-pt.kemdiknas.go.id/). Interviews were conducted with several lecturers and students from departments of communication sciences and journalism from several universities in Indonesia, such as Gadjah Mada University (located in Central Java), Padjadjaran University (located in West Java), Mataram University (located in West Nusa Tenggara), Surabaya State University (located in East Java), Lambung Mangkurat University (located in South Kalimantan), and Malikussaleh University (located in Aceh). Some issues explored were the existence of climate change issues in the curricula of the department, and their commitment to mainstream climate change issues in the courses. Interviews were conducted via telephone and email due to technical reasons as the interviewees came from various and different locations in Indonesia.

\section{Findings}

\section{A. Climate change issue and mass media in Indonesia}

Television is the most popular media in Indonesia with the number of households who own TV reaching 86.7 percent of total population, which is equivalent to 56.4 million households (Kominfo, 2015). Currently, there are 13 free to air (FTA) national TV stations in Indonesia namely, RCTI, SCTV, Indosiar, Trans TV, Trans 7, Metro TV, Global TV, TV One, Net TV, TVRI, ANTV, MNC TV, RTV, iNews TV and Kompas TV. The most popular TV programmes are news, soap operas, and music events (Kominfo, 2015). Some TV stations actually have a programme related to environmental issues, for example Jejak Petualang - Traces of Adventurer on Trans 7 TV, My Trip, My Adventure on Trans TV, and Mancing Mania-Fishing Mania on Trans 7. However, these shows tend to be tourism and entertainment programmes. Climate change issues have been raised on some talk shows that highlighted environmental and climate change issues, such as episodes of Kick Andy on Metro TV that invited environmental activists as its guests. In one of its episodes, Setetes Air untuk Kehidupan (A drop of Water for Life), the talkshow invited an 'environmental hero' called Sadiman, who has single-handedly planted trees in the forest area of Wonogiri, Central Java, for 19 years.

Even though television has still become 'the king' and new media has been growing rapidly, unlike in many other countries, print media consumption in Indonesia has increased (Austin et al, 2015). This positive trend in print media was followed by advertising cost increases in newspaper (see http://www.nielsen.com/ id/en/press-room/2016/Nielsen-Belanja-Iklan-Tumbuh-Positif-di-Tahun-2015. $\mathrm{html}$ ). Readers of newspapers in Indonesia seem to be more interested in political issues, entertainment, and sports. One of the largest and most popular newspapers in Indonesia is Kompas. This newspaper has more than two million readers and 
has reached the largest circulation of 530,000 copies each day in 34 provinces. Kompas has been published since 1965. Until now, Kompas is the most reputable newpaper in Indonesia. But, how has Kompas been covering the climate change issue so far? From content analysis research during January-July 2016, there were 196 articles on climate change (Figure 1). In 2015, the number of articles containing keywords 'climate change' in Kompas reached 381 with 330 articles in 2014. However, most articles that contained these keywords did not put this issue as the title or the main focus.

\section{Figure 1: Number of articles about issues on Kompas, 2016}

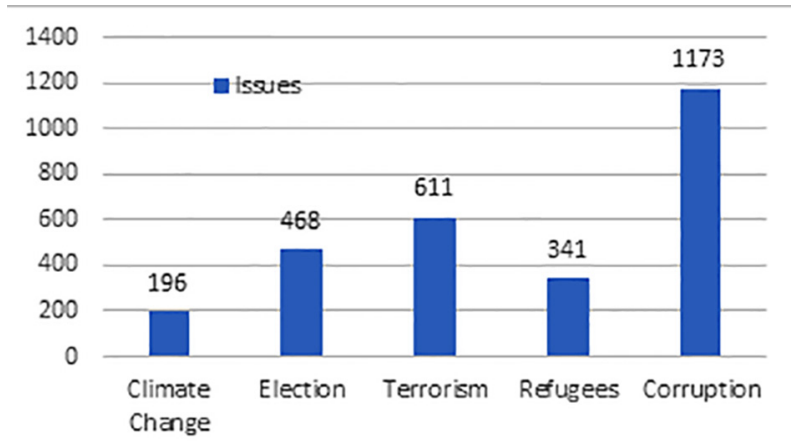

Note: Period from January to July 2016.

Figure 1 shows the comparative number of articles with keywords about climate change versus other public issues. The number of articles containing 'climate change' keywords are much fewer compared with other keywords like terrorism, elections, refugee issues, and corruption. The data indicated that there were 1,173 articles using the keyword 'corruption' on Kompas during January-July 2016. Corruption coverage is still the major topic of mass media in Indonesia. In the second level, the keyword 'terrorism' was found in 611 articles. Election issues were covered in 468 articles, refugees 341 articles, while some keywords which are strongly associated with 'environmental issues' such as climate change, environment, forest fire, smoke, drought, pollution, global warming, and conservation overall were only found on 196 articles (Figure 2).

Figure 2 indicated further details, including comparison of the number of articles with relevant keyword 'environmental issues' on Kompas from JanuaryJuly 2016. The keyword 'living environment' was the most often used in articles, approximately 576 articles, and the keyword 'conservation' was found in a total of 411 articles. Other keywords were climate change (196 articles), forest fire (171 articles) and drought (107 articles), global warming (48 articles) and haze (43 articles). 


\section{Figure 2: Number of articles about 'environmental issues'}

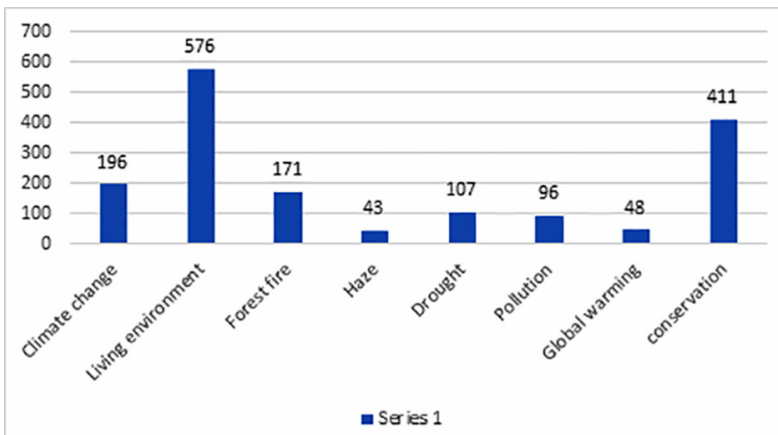

Note: On Kompas from January to July 2016.

\section{B. Journalism education in Indonesia}

The development of mass and new media contributes to the increasing number of Departments of Communication Science in Indonesia. Communication science has become one of the most popular social sciences fields in Indonesian universities. Geographically (Figure 3), the Department of Communication Science in Indonesia exists in all regions of Indonesia from the western part (Java and Sumatra), central part of Indonesia (Sulawesi, Kalimantan, Bali, NTT and NTB), to the eastern part of Indonesia (Papua and Maluku).

\section{Figure 3: Departments of Communication Science in Indonesia}

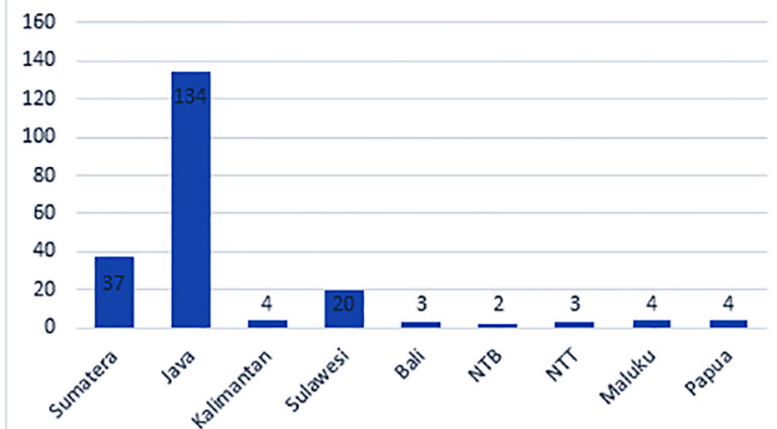

Note: Data compiled from Indonesian National Accreditation Board for Hiher Education (BAN_PT) 2016.

Every year, thousands of applicants apply to the departments of Communication Sciences in various state universities, but few of them are accepted due to limited capacity. The Department of Communication Sciences, Gadjah Mada University, for instance, only accepted 75 applicants for this major through a tight selection process from a total of 5000 applicants in 2015. Similarly, University of Indonesia received 6000 applicants and accepted only 80 of them 
as communication sciences students. In the eastern part of Indonesia, The Department of Communication Sciences in Hasanuddin University accepted 45 students out of 3000 applicants. Unsuccessful applicants may then enroll in private universities, which can accommodate more students. The Department of Communication Sciences in University of Muhammadiyah Yogyakarta attracted approximately 2344 applicants with 565 of them being accepted. The University of Multimedia Nusantara in Jakarta accepted 541 applicants out of 1248 who applied in 2015.

Since the number of prospective students in this major increases rapidly, more Indonesian universities, both state and private have been opening Departments of Communication Sciences. In 1999, there were only 40 Departments of Communication Sciences in universities or higher education institutions in Indonesia (Nasution, 2000). In 2016, this number had grown to 212. In addition, 28 universities also provide masters programmes in Communication Sciences. Some universities in Jakarta, such as University of Indonesia, Sahid University, as well as Padjadjaran University in Bandung, have opened doctoral programmes. This situation leads to an unbalanced ratio between the number of lecturers and students, particularly in private universities. On the other hand, the ratio of lecturers and students in public universities is relatively equal since they limit the number of students accepted.

Generally, departments of Communication Sciences in Indonesia are managed under the supervision of the Higher Education Ministry of Republic Indonesia. Besides, there are also departments of Communication Sciences that are under supervision of the Ministry of Religion Republic Indonesia. They are Islamic universities such as Islamic state universities and Islamic private universities managed by Indonesia's largest Islamic organisations, Muhammadiyah and Nahdlatul Ulama (NU). These Islamic universities develop departments of Communication Sciences as well Islamic broadcasting departments. According to the data from the Accreditation Board of Higher Education (see http://ban-pt. kemdiknas.go.id/), the total number of Islamic Communication and Broadcasting Departments are 116. These numbers are mostly situated in western Indonesia. Unlike general departments of Communication Sciences in Indonesia, communication sciences in Islamic universities belong to the Social and Dakwah Faculty where they are seen as key elements of Islamic propaganda. The number of departments of Islamic Communication and Broadcasting is growing rapidly along with the growing interest to study communication sciences in Indonesia.

Journalism is a programme under the Department of Communication Sciences. Other programmes are public relations, media management, strategic communications, advertising, communication development, or other specific fields. Communication sciences has opened as a faculty at Padjadjaran University, West Java, with journalism becoming a department under the Faculty of Communication Sciences. In other types, at the Gadjah Mada University, Yogyakarta (central 
part of Indonesia), journalism only became a programme along with advertising, public relations, and entertainment media. It can be seen that the number of students who choose to study journalism at several universities, is always smaller than other specialisations in strategic communications, public relations or advertising. From the interviews, some lecturers in the Department of Communication Sciences, Lambung Mangkurat, South Borneo, as well as in Gadjah Mada University, Yogyakarta, said that the number of journalism students tended to be less than the number of students of other specialisations. The same tendency occurred in most departments of Communication Sciences in Indonesia. There is a paradox situation with the tendency of journalism student numbers to decrease amid a high demand of communication sciences in Indonesia.

\section{Analysis}

From the media and climate change perspective, the limited coverage and weak framing in climate change by Indonesian mass media has impacted on the climate change in that the issue has not been noticed as important. It could be concluded that there are some challenges to mainstreaming the climate change issues for public discussion. The coverage of climate change issues faces some challenges, both internal and external. Internal factors are related to the dynamic of media journalism and decision making process (i.e. some unique characters of climate change issues versus the credo of journalism and problems of coverage on scientific issues) and external factors (i.e. mediated politics and the politics of climate change). Assumption increases that the condition of climate change journalism weakens because Indonesian social politics atmosphere does not consider climate change as a relevant issue. Climate change is more popular on the international agenda, and many relevant actors fail to transfer this issue into a more local context. This situation contributes further to the difficulties of sharing and understanding the approaches and encouragement of mitigation of global warming.

From the system perspective, the structure of Indonesian journalism education system consists of internal element system, such as educational actors and educational infrastructures. Educational actors comprise lecturers and students. Educational infrastructure consists of curricula, academic environment and structure of management (faculties, departments concentrations), and the policy of the Higher Education Ministry at the national level. In the external environment, there are also many problems. They are: demanding socio-political issues such as economy, politics, environment, and climate change issues. The Indonesian journalism education system is not adaptive to respond to its existing demanding environment. It is categorised as not adaptive because there are so many problems existing. However, the internal system does not proceed as an important issue. The issues of climate change exist outside the system and are always positioned as part of the external environment. 
Indonesian journalism education system development is too general and does not give special attention to journalism education for climate change. The issues of climate change are not placed as a part of the system, because the internal system does not make sense of it as an important problem. The autopoietic mechanism is weak because the system is not adaptive to communicate and give feedback to their environment. Fast response to the system should create an internal system to answer the needs.

From the perspective of journalism education, it shows that within Indonesian journalism education system, there exist problems in some layers. The system is not responsive enough to give feedback to many substantial problems, which should be developed to strengthen the awareness of students in climate change issues. Curriculum designed to answer climate change issues does not exist. No special class to discuss journalism and climate change, climate change discourses are under development and there is not much contribution from the journalism education or university in general to answer climate change issues.

At the micro level, there is a lack of lecturers who are highly skilled in climate change issues. The issue of climate change has specific characteristics of knowledge. Lecturers have to learn how to find the entry point to cover specific themes about climate change, especially how to communicate the problems. Lecturers should understand the issue comprehensively, and be able to inspire students to have high skills in covering climate change issues. At a messo or organisational level, the media or departments of Communication Sciences in Indonesia have less concern with the real problems existing in their environment. They failed to position their existence through institutional visions. In this context, to realise the goal, the department can show their responses by building adaptable vision, mission and journalism curricula which are oriented on environment conservation. If the Department of Communication Sciences can show their clear position and involvement in the movement to reduce climate change issues, they can play a larger role in reducing the impact of climate change, as one of the real problems that they should address.

At a macro level, the media and departments of Communication Sciences face difficult circumstances. In society, public, private and political level, reactions to climate change are still relatively small to what powerful scientific, economic and moral arguments demand. The situation is uneasy because the Indonesian mass media landscape was coloured by a private-commercial atmosphere. Entertainment programmes with low quality cannot be hindered in this situation. Climate change programmes have presented only in good quality talk shows and on the news programmes. However, both exist in a limited numbers.

The quality of journalism education in mainstreaming climate change issues has many obstacles regarding the soft structure (substantial, skill and competence) and hard structure to the situation and condition in communication or journalism 
department. Several potencies and challenges for Indonesia are:

- Big numbers of Communication Departments in Indonesia have real potential. However, at the same time this is not in line with the strong engagement in climate change issues.

- Students favour concentrations of strategic communication over the journalism. The students prefer mass communication, strategic communication (PR and Advertising) and media entertainment to journalism studies. With this structure, communication departments in Indonesia focus more in preparing their alumni to work and serve in the industry.

The struggle to establish strong climate change journalism in Indonesia still has a long way to go. More efforts and comprehensive actions are intensely needed to search for the the ideal model of journalism education. The skills on how journalists handle phenomena based on science perspective is very important. Journalism should keep up with the science to catch important phenomena in the society. At a practical level, media and communication departments can invite scientists to train students on how the logic of science works. They can learn the reasons for the facts or finding in science.

The specific characteristics and the uniqueness of climate change coverage need to be acknowledged by the students in journalism institutions. Although, there are some requirements - internal and external — to be fulfilled to achieve ideal conditions to succeed for mainstreaming climate change issues, particular factors namely specific competence to cover the climate change issues, and strengthening structure in the journalism education to support coverage in climate change issues are really needed to be considered.

\section{The future of Indonesian journalism education for climate change}

Although the academic climate in journalism education is lacking, from the statements of young scholars and lecturers in Indonesia there is still hope that the climate change issue will become really important for students in journalism or media and communication departments. In the future, efforts to strengthen the climate change discourse in journalism education should be realised through some activities:

1. Mainstreaming climate change issues through immersion of the climate change issue in many subjects or courses. Although there is no specific course about climate change, basically the issue can be discussed in many subjects which involve all phases of journalism. Cited from Carvalho and Burgess, it should be mind 3 phases of journalism in which the main issues can be discussed (Boykoff \& Timmons, 2007). Firstly, news production phase, secondly, public discourse phase, and thirdly, media consumption and personal engagement with climate change issues. 
Relevant subjects which could be developed are starting from economy politics, media campaign techniques, strategic communication, and strategic framing analysis.

2. Improving public awareness on climate change through strong journalism. The specific characteristics of climate change demand some competencies in covering climate change issues. As reflection of the idea of Smith (2005), particularly about the internal factors influenced decision making process, the students acknowledged that the narrative of climate change in dramatic terms will make it difficult for people to connect with the decisions about lifestyle and resource use that they make every day. To avoid it they have to learn the specific narrative suitable for the climate change issues, also they will have other perspectives to reflect the uncertainty, to prove the truth in the sense of climate change and the sustainable development.

It needs several requirements to activate journalism education as the main pillar of climate change issues. Coping with the climate crisis is inevitable for saving the future. The role of science in general and specific institutions and universities plays very crucial role. Communication department students, who in the future will be journalists, should learn the basic principle that the 'journalism as the software' of mass communication is an important tool to serve and generate issues in society. It is really necessary to prepare students to cover climate change in smart, proportional and professional ways. This competence needed to rejuvenate the society with new ideas and inspire citizens for better living is the main function of mass media. To achieve this ideal condition, finding and developing best learning strategy in climate change issues is not only necessary but also fruitful for a better future.

\section{Note}

1. The Australian Centre for Independent Journalism (ACIJ) was closed by the University of Technology Sydney after a final seminar paying homage to its quarter century of journalism and media training on 29 April 2017.

\section{References}

Arlt, D., Hoppe, I., \& Wolling, J. (2011). Climate change and media usage: Effects on problem awareness and behavioural intentions. The International Communication Gazette, 73(1-2), 45-63. DOI: 10.1177/1748048510386741.

Austin, A., Barnard, J., \& Hutcheon, N. (2015). Media Consumption Forecasts 2015. ZenithOptimedia.

Ayers, J., Huq, S., Wright, H., Faisal, A.M., \& Hussain, S.T. (2014). Mainstreaming climate change adaptation into development in Bangladesh. Climate and Development, 6(4), 293-305, DOI: 10.1080/17565529.2014.977761. 
Bacon, W. (2012). An innovative direction in academic journalism. Pacific Journalism Review, 18(2), 153- 165. DOI: http://dx.doi.org/10.24135/pjr.v18i2.270

Bappenas. (2009). Indonesia climate change sectoral roadmap. Jakarta: ICCSR, Republic of Indonesia.

Baran, S.J. (2006). Introduction to mass communication: Media literacy and culture. Boston: McGraw-Hill.

Boykoff, M.T., \& Boykoff, J.M. (2007). Climate change and journalistic norms: A case-study of US mass-media coverage. Geoforum, 38, 1190-1204. DOI: 10.1016/j. geoforum.2007.01.008

Boykoff, M.T., \& Timmons, J.R. (2007). Media coverage of climate change: Current trends, strengths, weaknesses. Human Development Report 2007/2008 : UNDP.

Castells, M. (2009). Communication power. New York: Oxford University Press.

Dotson, D.M., Jacobson, S.K., Kaid, L.L., \& Carlton, J.S. (2012). Media coverage of climate change in Chile: A content analysis of conservative and liberal newspapers. Environmental Communication, 6(1), 64-81, DOI: 10.1080/17524032.2011.642078.

Folkerts, J. (2014). History of journalism education. Journalism \& Communication Monographs, 16(4), 227-299. DOI: 10.1177/1522637914541379.

Garnaut, R. (2009). Climate change and Indonesia: In honour of Panglaykim, Bulletin of Indonesian Economic Studies, 45(1), 107-116, DOI: 10.1080/00074910902836163.

Gavin, N.T. (2009). Addressing climate change: A media perspective. Environmental Politics, 18(5), 765-780. DOI: 10.1080/09644010903157081.

Gess, H. (2012). Climate change and the possibility of 'slow journalism'. Ecquid Novi: African Journalism Studies, 33(1), 54-65. DOI: 10.1080/02560054.2011.636828

Hanitzsch, T. (2001). Rethinking journalism education in Indonesia: Nine theses. $\mathrm{Me}$ diator, 2(1), 93-100.

Hwa, A.P., and Ramanathan, S. (Eds.) (2000). Communication education in ASEAN. Singapore: AMIC.

Kenix, L.J. (2008). Framing science: Climate change in the mainstream \& alternative news of New Zealand. Political Science, 60(1), 117-132.

Knight, K.W. (2016). Public awareness and perception of climate change: A quantitative cross-national study, Environmental Sociology, 2(1), 101-113, DOI: $10.1080 / 23251042.2015 .1128055$

Krippendorf, K. (2004). Content analysis: An introduction to its methodology. London: Sage Publications.

KOMINFO. (2015). Buku Saku Hasil Survey Indikator TIK 2015 Rumah Tangga dan Individu. Jakarta: Pusat Penelitian dan Pengembangan Penyelenggaraan Pos \& Informatika, Badan Penelitian dan Pengembangan Sumber Daya Manusia, Kementrian Komunikasi \& Informatika.

Leiserowitz, A. \& Howe, P. (2015). Climate change awareness and concern in 119 countries. Yale Program on Climate Change Communication. Retrieved from http:// climatecommunication.yale.edu/publications/analysis-of-a-119-country-surveypredicts-global- climate-change-awareness/.

Luhmann, N. (2000). The reality of mass media. Stanford: Stanford University Press

McQuail, D. (2010). McQuail's mass communication theory. London: Sage Publications. Nasution, Z. (2000). Communication education and media needs in Indonesia. In A.P. Hwa \& S. Ramanathan (Eds.), Communication Education in ASEAN (pp. 45-76). Singapore: AMIC. 
Nisbet, M.C. (2009). Communicating climate change: Why frames matter for public engagement. Environment: Science and Policy for Sustainable Development, 51(2), 12-23, DOI: 10.3200/ENVT.51.2.12-23.

O’Neill, S., \& Nicholson-Cole, S.. (2009). Fear won't do it: Promoting positive engagement with climate change through visual and iconic representations. Science Соттиnication, 30: 355-379.

Paulus, R.Y \& Hindmarsh, R. (2016): Addressing inadequacies of sectoral coordination and local capacity building in Indonesia for effective climate change adaptation. Climate and Development, DOI: 10.1080/17565529.2016.1184609.

Putrawidjaja, M. (2008). Mapping climate education in Indonesia: Opportunities for development. Jakarta: Climate Education Research-British Council Indonesia.

Reese, S.D. (2001). Prologue—Framing public life: A bridging model for media research. In S. D. Reese, O. H. Gandy Jr. \& A. E. Grant (Eds.), Framing public life: Perspectives on media and our understanding of the social world (pp. 7-31). New Jersey: Lawrence Erlbaum Associates Inc.

Ritzer, G. (2011). Sociological theory. New York: McGraw-Hill.

Sampei, Y., \& Aoyagi-Usui, M. (2009). Mass-media coverage, its influence on public awareness of climate-change issues, and implications for Japan's national campaign to reduce greenhouse gas emissions. Global Environmental Change, 19, 203-212.

Schmidt, A., Ivanova, A., \& Schafer, M.S. (2013). Media attention for climate change around the world: A comparative analysis of newspaper coverage in 27 countries. Global Environmental Change, 23, 1233-1248.

Shehata, A., \& Hopmann, D.N. (2012) Framing climate change. Journalism Studies, 13(2), 175-192. DOI: 10.1080/1461670X.2011.646396.

Siña, M., Wood, R.C., Saldarriaga, E., Lawler, J., Zunt, J., Garcia,P. , et al. (2016). Understanding perceptions of climate change, priorities, and decision-making among municipalities in Lima, Peru to better inform adaptation and mitigation planning. PLOS ONE 11(1): e0147201. doi:10.1371/journal. pone.0147201.

Smith, J. (2005). Dangerous news: Media decision making about climate change risk. Risk Analysis, 25(6), 1471-1482. DOI: 10.1111/j.1539-6924.2005.00693.

Takahashi, B., \& Meisner, M. (2012). Climate change in Peruvian newspapers: The role of foreign voices in a context of vulnerability. Public Understanding of Science, 22(4) 427-442. DOI: 10.1177/0963662511431204.

Dr Hermin Indah Wahyuni is director of the Center for Southeast Asian Social Studies (CESASS) and a lecturer in the Communication Department, Faculty of Social and Political Sciences, Universitas Gadjah Mada (Gadjah Mada University), in Yogyakarta, Central Java, Indonesia.

hermin_iw@ugm.ac.id 